CATALAN REVIEW

Catalan Review



You are accessing the Digital Archive of the Catalan Review Journal.

By accessing and/or using this Digital Archive, you accept and agree to abide by the Terms and Conditions of Use available at http://www.nacs-

catalanstudies.org/catalan_review.html

Catalan Review is the premier international scholarly journal devoted to all aspects of Catalan culture. By Catalan culture is understood all manifestations of intellectual and artistic life produced in the Catalan language or in the geographical areas where Catalan is spoken. Catalan Review has been in publication since 1986 .
NORTH

AMERICAN

CATALAN

SOCIETY
Esteu accedint a l'Arxiu Digital del Catalan Review

A l' accedir i / o utilitzar aquest Arxiu Digital, vostè accepta i es compromet a complir els termes i condicions d'ús disponibles a http://www.nacs-

catalanstudies.org/catalan_review.html

Catalan Review és la primera revista internacional dedicada a tots els aspectes de la cultura catalana. Per la cultura catalana s'entén totes les manifestacions de la vida intel lectual i artística produïda en llengua catalana o en les zones geogràfiques on es parla català. Catalan Review es publica des de 1986.

\title{
Ramon Llull as Novelist: The Visionary Realism of Blanquerna Elena Rossi
}

Catalan Review, Vol. IV, number 1-2 (1990), p. 279-297 


\title{
RAMON LLULL AS NOVELIST: \\ THE VISIONARY REALISM OF BLANQUERNA
}

\author{
ELENA ROSSI
}

R.W. Southern's classic study Western Views of Islam in the Middle Ages does not include a discussion of Ramon Llull, for whom Islam was a chief interest and a burning one. This omission is explained by Southern in a footnote, in this manner:

On almost every score he deserves a much greater place in these pages than I have given him. I have refrained, partly because, with his vast output of more than 200 works, he is a special subject in himself, and partly because in all this torrential energy there seems to me a streak of madness to which I cannot do justice. $^{I}$

The illustrious historian openly acknowledges his perplexity in front of a figure such as R. Llull and one has to respect Southern's sense of fairness in preferring not to deal with the "Great Majorcan» in view of his own spontaneous prejudiced reaction which classifies Llull in fact as a possible lunatic.

The candid admission of a puzzled historian provides, in this case, an appropriate starting point for the literary critic. What intimidates the historian and prompts him to place R. Llull outside the relatively sedate world of other mediaeval scholarly writers is a quality of visionary insight, thanks to which Llull transcends his own age to become the universal figure that he is. The Doctor Illuminatus, the "Apostle of the Infidels» is in fact a great poet, in the Crocean sense of the word: his «streak of madness" is his creative imagination, unrestrained, constantly striving to convert the essence of human experience from worldly to reli-

${ }^{\mathrm{I}} \mathrm{R}$.W. Southern, Western Views of Islam in the Middle Ages (Cambridge, Harvard Univ. Press, 1978) 72. 
gious, and to illustrate this conversion in terms that might persuade others to follow the divine way, to rediscover the divine in themselves.

Nothing illustrates better this attempt than his literary masterwork, the Libre de Evast e Blanquerna, generally shorttitled Blanquerna. Here the poet and the divine merge; their visionary insight creates a fictional world where the reality of the time is transformed, slowly, into an ideal one, retaining, however, its human essence, hence the seemingly contradictory title of the present study. The coexistence of the visionary and the realist, excluded by the factual strigency of historical analysis, is affirmed poetically in Blanquerna, just as it was affirmed de facto in Ramon Llull's real life. The result of this coexistence is a splendid prose work, nearest in genre to a novel.

One is tempted to use the adjective "revolutionary" in describing Blanquerna, although there was nothing similar in the literature before it against which to rebel. Yet there is a newness in its artistic conception which only Dante will match in the Divina Commedia. In both works the reader observes that, after many centuries, poetical imagination has finally cast off its fetters and is allowed to enlighten and nurture the artistic vision of the authors. This is the result, to a certain degree, of a new linguistic awareness, thanks to which both Dante and Llull are the creators of the modern literary idiom in their respective countries.

However, what brings Llull so near the Divine Poet is precisely his visionary power. Like Dante, Llull is a keen observer of the historical reality around him. Like Dante, he transcends this reality to recreate it in an ideal form under the impulse of his own visionary wisdom. Dante's supernatural world is as «ideal» as Blanquerna's utopian religious state at the end of the novel. Both «ideal» worlds incorporate the reality of the historical time of their authors in a desperate effort to improve it. Both creations are visionary, and yet also realistic in their portrayal of contemporary society and in their references to the problems that plague it, references explicitly made by Dante, less so by Llull. 
What differentiates Llull from Dante is his avoidance of political invective, his reluctance to denounce specific individuals. $\mathrm{He}$ is as fully aware as Dante is of the corrupted, unfair state of society, both in its secular and in its religious facets, but while Dante has lost hope of seeing it reform voluntarily within the short run, Llull has not. And it is this hope, this near certainty that lends Blanquerna its true visionary tone. Dante's visionary power springs, as does Llull's, from absolute religious faith; nevertheless Dante's is coloured indelibly by a pervasive sense of disillusion, while Llull's remains pristine throughout Blanquer$n a$. This is partly a reflection, no doubt, of the two mens' chosen roles in life: Llull, unlike the politician Dante is a religious missionary, who believes that his task has been assigned to him directly by God, through miraculous intervention. His zeal is therefore unlikely to be daunted by any wordly disappointment. In Blanquerna and in the Divina Commedia there palpitates the longing spiritual regeneration which animated a great segment of mediaeval society at the end of the thirteenth century, and to which the newly formed literary idiom of Llull and Dante gave expression with unsurpassed intensity. It is useful to juxtapose Llull to Dante not in view of establishing Blanquerna as the Catalan equivalent of the Divina Commedia, but rather to illustrate how similar artistic visions and ethical concerns link ideally together these two authors and shape their literary innovations. The seminal part played by Llull in the development of the Romance narrative genre is as real, though less studied, as Dante's fundamental and generally recognized contribution to Romance poetic tradition. A discussion of Llull's basic narrative strategies, some of which he inaugurated, constitutes the subject of the present study.

In contrast to the massive theological and literary pillars established by Dante for the Divina Commedia, the premises on which Llull bases the story of Blanquerna are visionary in their very simplicity: man owes his very life to God, physically because 
God created him and put the world at his disposal for his sustenance, spiritually because through God's Incarnation he has been redeemed from mortal sin and can attain eternal life. Therefore man is "God's tabernacle»: with his body he must exalt Him, with his actions he must magnify Him. In Llull's view, it is inconceivable that once taught these basic truths, man will not voluntarily permeate every moment of his life with the awareness of his marvelous link with the Creator, since: «Natural cosa és que, aytant com l'enteniment humà és mills endreçat a entendre Déu, aytant la volentat és pus aparellada a amar Déu e a desamar peccat». ${ }^{2}$ Hence the importance given to instruction throughout this work. Ignorance prevents devotion. Learning is seen as a fundamental and indispensable act, which permits and completes the giving of one's own self to God. The axiom on which Llull's faith is based is: «Plorar, conèxer amar! $»^{3}$ signifying the perfect integration of feeling and reason which gives Lullian devotion its peculiar, exciting richness and vitality.

Although Blanquerna is clearly a book with a didactic aim, a book written «per donar doctrina con deja hom viure en est món per tal que en l'altre eternalment sia en la glòria de Déu», ${ }^{4}$ Ramon Llull would not be the visionary he is if he did not transform the experience of learning into a moment of total transport, if he did not infuse instruction with passion, if he did not, in fact, "god wild " with feats of imaginative pedagogy. His narrative technique presents us with a magnificent sequence of "visions» whose didactic purpose he conveys either through the familiar façade of everyday events or through the poetic glitter of fanciful situations, or through very exciting adventures. In Blanquerna we meet with a self-conscious preceptor who while not bent on dazzling his audience with a display of his literary art succeeds neverthe-

${ }^{2}$ Ramon Llull, Libre de Evast e Blanquerna, ed. Mn. Salvador Galmés, 4 vols. (Barcelona, Barcino, 1935-1954), 2, 200.

${ }^{3}$ Llull, Blanquerna, 2, 41.

4 Llull, Blanquerna, 3, 185 . 



truly phantasmagoric: with the exception of the period of his papacy, which takes him to Rome, and despite some incidental references to historical events, the world through which he travels remains purposely undefined. Although realistically described and often geographically recognizable, it remains a fictional "grey» area which the fantasy of the author populates innumerable protagonists: unforgettable major ones - Evast, Aloma, Natana and her mother Nastàsia, Narpan, the Emperador, the Juglar de Valor, Ramon himself «lo Foll» — and a whole host of less important ones - the Cellerer, the Artiacha, the Camarlench - pawns manoeuvred by the fancy of the artist to serve his didactic scope. ${ }^{6}$

Llull was well aware however, of the danger of boring his audience: «e-l apostoli demanà al cardenal si havia vist plorar null home a son sermó. Lo cardenal respos que no, mas que havia vists durmir molts hòmens dementre que ell preycava». ${ }^{7}$ It is not surprising then that, while he divests his prose diction of any unnecessary rhetorical hindrances and keeps it terse, cogent, always clear, at the same time he should also use it to create a colourful, exciting, imaginary world. A story-teller world, where nothing distracts the reader from the action going on it; where the pace of the narration is fast, at times so incessant as nearly to approach frenzy:

Tant era frevent e devot lo cardenal en honrar lo poder de Déu, que diverses oficis establí a honrar lo poder de Déu; cor $\mathrm{a} \cdot \mathrm{I} \cdot$ home donà ufici que anàs per lo món preycant e cridant que no's confiàs hom en poder de riquees, ni d'amics, ni de saviea, ni de jovent, ni d'avuyrs, sorts, avaranys, ni en nulls altres poders per

5 For an introduction to Blanquerna see M. de Riquer, Història de la Literatura Catalana, 2 vols. (Barcelona, Edicions Ariel, 1964), I, 260-92.

${ }^{6}$ About the validity of Llull's anthropological and geographical notions, see Riquer, Història I, 284; see also Friedrich Heer, The Medieval World (New York, The New American Library, n.d.) 307.

7 Llull, Blanquerna 2, 240. 
los quals hom pert la gràcia del poder divinal. Altre ufiçial féu lo cardenal, qui cridava lo poder de Déu ésser tan gran, que pudia fer totes coses, pus que no sse'n seguís peccat. Altre uficial cridava que Déus no pudia fer peccat, per ço cor peccat e no poder són coses concordants e contraries a poder e a virtuts, qui-s concorden. Altre uficial cridava que Déus, en les creatures, no usava del seu poder, cor més coses pudia fer que no fahia. Altre cridava que Déus, en sa trinitat, fahia tot ço que pudia. D'altres uficials hi havia molts, qui honraven lo poder de Déu, e tots havien regla e doctrina com lo poder de Déu honrasen e benehisen; e enfre los altres uficials hi havia I. ofiçi de mostrar per natura com pudia hom mortificar vicis, ni fortificar virtuts, ni plorar sos peccats, altre ufiçi hi havia de un home que portava un ram e un auçel, e menava un cha, e cridava que no era null home qui pugués fer una fulla del ram, ni una ploma del auçel, ni I. pel del cha, ni una ungla de sa mà. ${ }^{8}$

A description such as the one above is bound to hold the reader's or the listener's attention, while exemplifying in a tangible way the mood evoked by the opening line "Tant era frevent e devot», with the adjective frevent ultimately setting the pace. As can be seen from this excerpt, quite a typical one, the scenes Llull evokes are most often public, usually street scenes or religious meetings, recurrently punctuated by outbursts of clamour, sudden wailings, or eccentric apparitions, such as the one of the last "crier", a miniature repetition of the surrealistic arrival at the Papal court of Ramon himself in the guise of the "Foll». Communicating, urging, pleading, converting, are all brought about by vocal efforts; Llull's fictional milieu is full of sounds, of bustling activity conveyed by noise. The expressiveness of the scenes seldom is conjured by description of hues of colour or by plastic details, yet the scenes are always vivid and exert on the modern reader a special, almost operatic appeal. In this passage alone, the verb cridar is employed six times.

While this sort of reiteration is a wonderful device to hammer people into listening, it also reflects, in a blatant fashion, the instructional philosophy of Llull, for whom no true learning is

${ }^{8}$ Llull, Blanquerna 2, 21 1-12 (emphasis added). 
possible, unless the affective interest is captured, unless the emotions are stirred first:

Esdevench-se una vegada, que un fill de conte anava a Bulunya per ohir Leys; $\mathrm{e}$ lo cardenal, qui anava a Bulunya... encontrà's ab aquell fill de compte, e dix-li tantes de bones paraules per lo camí, que l'enamorà de la sciència de Tehologia, la qual és pus neçessària a clergue que sciència de Leys; e per açò aquell fill de comte se'n tornà a Paris e après Teologia, de la qual sdevench maestre."

This brief episode is typical of the several dozen that Ramon Llull includes in the novel. Each of them, no matter how minor, constitutes either a stage in Blanquerna's journey towards the fulfillment of his own destiny or a moving illustration of the success of Blanquerna's mission. Here, the key words are affective ones: bones, enamora. Enamorà conveys the culminating effect of this encounter and is, in a pointed and clever fashion, juxtaposed to sciència: their proximity on paper is a reflection of their contradictory, nevertheless, real, reconciliation in the story. Although Llull's intention is to instruct through his art, not to display it, his ability to manipulate language with imaginative cleverness makes Blanquerna an aesthetic breviary as well as a devotional one. Even the «esdevench-se una vegada» at the beginning of the above passage creates a mood of expectation, prepares the reader for some tale of wonder. The formula «esdevench-se» is Llull's customary way of introducing his exempla and tales; its redolence of secular story-telling is calculated to assure at least an initial moment of interest on the part of the mediaeval reader or listener to whom he addresses himself.

As for the actual stories, the author's imagination seizes on any available narrative device to hold the reader captive, a witness to the graphic representation of Llull's vision of the truth. He guides his audience from the relative familiarity of the initial ambience of Blanquerna's journey, a mediaeval town, into a mar-

${ }^{9}$ Llull, Blanquerna 2, 205. 
velous wilderness where most unforeseen events take place and where occur the strangest encounters. A «bell palau obrat molt noblement" suddenly materializes in the middle of a thick wood. ${ }^{\text {to }}$ It is the Palace of the Ten Commandments and Blanquerna actually meets these venerable personages which the fantasy of Llull brings magically to life, just as shortly after it will personify $\mathrm{Fe}$, Veritat, Enteniment and Devoció, in a cleverly adapted religious allegory borrowed directly from the conventions of the amour courtois literature. ${ }^{11}$ Although neither $\mathrm{C} i$ far nor Amadis are yet officially on the literary scene of the Península we find in parts of Blanquerna clear anticipations of their genre, most notably in the episode of doncella, ${ }^{12}$ the one of Narpan or even in a strikingly graphic vignette such as the following:

Aprés un poch de temps que lo merchader se fos partit de Blanquerna, vench un home a peu, molt cuytosament. Carregat fo de oques e de gallines, que portava a son coll. Blanquerna li demanà si sabia, en tota aquella forest, null loch lon pogués abitar, lo qual loch fos en alcuna muntanya on hagués fontana e agués alcuna fruyta salvatge d'on pogués home viure en vida ermitana. ${ }^{{ }^{3}}$

Such simplicity also brings to mind the naive stylized depictions of social dealings that appear so frequently in the works of mediaeval artists, especially the Sienese painters.

The interpolations of exempla also are often anticipatory of works such as Cifar, Conde Lucanor, Arciprestre de Talavera,

to Reminiscent of Andreas Capellanus, The Art of Courtly Love, ed. John Jay Parry (New York, F. Ungar Pub. Co. 1959, rep. of 1941 Columbia Univ. Press ed.) I80; anticipatory of D. de San Pedro, Carcel de Amor, ed. K. Whinnom (Madrid, Castalia 1971) 2, 84 .

${ }^{11}$ Which in turn derived this allegorical mode from the Latin writers. See for example Ovid's Amores, tr. Guy Lee, (London, J. Murray n.d.) Iii 3 I-32 and $35-36$.

${ }^{12}$ See Riquer, Història I, 278.

${ }^{13}$ Llull, Blanquerna I, 228. 
and reminiscent of their common antecedent Disciplina Clericalis. At other times the Fioretti and other Lives of saints are brought to mind, although Llull's narration is never as reverential in tone, or as naive in content as the Franciscan Lives usually are. The purpose of the present study however, is not to trace these literary links, but rather to acknowledge them as evidence of the efforts of Ramon Llull's poetical imagination to concretize for his readers the steps necessary to achieve personal salvation while participating in the gradual transformation of society from secular to religious. The redemption of society, with the concomitant conversion of all infidels, pagans and savages, is well on the way to being accomplished by the end of the novel, and a vast Catholic bureaucracy, complete with its own set of spies and denouncers rather sinister and Inquisition-like, is well entrenched in a paternalistic state. The streets not only in Rome, but elsewhere, are constantly trodden by scores of «criers» who, shouting, chastize, admonish, request, beg, scold or simply proclaim the mysteries of the faith to the passing multitudes. The final impression, at least for the modern reader, is one of chaotic confusion and overwhelming, although holy, turbulence; truly a visionary panorama.

Throughout the narration, Llull's faith in the feasibility of achieving such a world-wide conversion is undaunted, and he is careful to illustrate each reforming step in a concrete, lucid manner, so it will be clearly undestood and clearly followed. The lucidity with which he presents the solution to just about any question concerning private salvation or gradual public reform is impressive. The absence of miracles resulting from God's direct intervention, increases the realistic validity of Llull's work and is a reflection of Llull's basically positive, confident view of the human powers of self-regeneration. Equally impressive are Llull's powers of persuasion: aided by his mastery of the narrative idiom and animated by his passion for God and compassion for his fellow man, his arguments are always cogently relevant, his inno- 
vations, whether of a strictly religious or of a more social nature, always consistent with the substance of the ideal world he is envisioning and that his artistic imagination makes tangible. Blanquerna is a supreme flight of fancy, and only in this light can one appreciate the two contradictory sides of its author's temperament and reconcile them.

The fact that his new social order is impossible to implement and downright arbitrary in historical terms, does not invalidate his view of human experience and of the nature of man which he so vibrantly extols in the novel. He is an acute observer of human behaviour. His psychological acumen is remarkable, particularly at a time when, as Huizinga points out in his classic study of the Middle Ages, there was a tendency to judge situations and people in a rather simplistic fashion. ${ }^{14}$

Llull shows his knowledge of human nature in the way he. depicts the character of the main protagonists of the story. In addition, he is tireless in analyzing the reactions and motives of his fellow humans in a manner which strikingly anticipates our century's psychological discoveries. The institution of the "criers" and the duties assigned to the Canonges impress us for example, as a rudimentary attempt at psychological conditioning:

Aprés ordenà l'apostoli que hòmens devots e de santa vida anassen tors jorns per les carreres de les çiutats e de les viles, dient les consideracions de les infernals penes e de la celestial glòria, per tal que les gents n'aguessen tots jorns en memòria les penes infernals e la glòria de paraís. ${ }^{\text {} 5}$

Here the key words are: tots jorns, dient, infernals, penes, celestial glòria, and aguessen... en memòria. By constant repetition (tots jorns, dient) basic concepts highly charged with emotio-

${ }^{14}$ Huizinga, J. The Waning of the Middle Ages (London, Edward Arnold, 1937) 214 .

is Llull, Blanquerna, 2, 242. 
nal meaning (infernals penes, celestial glòria) are literally engraved in people's consciousness (aguessen... en memòria).

His psychological perspicacity is enhanced by a compassionate perception of the sufferings of his fellow man. Although Blanquerna in his travels systematically attempts to convert the people he encounters to a Christian interpretation of the events which befall them - and does so with an intensity and abnegation which are truly visionary - nevertheless he effectively and lovingly manages to relieve their grief. The unforgettable episode of the sheperd whose seven-year-old son is killed by the wolf is an exquisite example not only of Ramon Llull's narrative penchant and its powers of concrete depiction, but also of how the visionary and the realistic sides of his temperament, reconciled by compassionate empathy, become the tool for emotional healing.

The 230 lines within which is contained the episode of the pastor are the illustration of Consolació, and would deserve a lengthy analysis to themselves. Llull's prose, completely divested of superfluity, summarizes the sequence of events in a few masterly strokes:

Sdevench-se que-l pastor s'adormí... e-l infant se lunyà d'aquell loch on son pare durmia. Un lop venia al bestiar, e atrobà l'infant, e pres aquell. Als crits quel infant gità con lo lop lo pres, se despertà lo pastor, e viu que lo lop se'n portava son fill. Lo pastor ab sos cans encalçà lo lop; mas ans que.l hagués attent, hac lo lop devorat e mort son fill, e li ach menjada la corada de son ventre. ${ }^{x 6}$

The predominant use of verbal forms is typical of Llull's narrative diction and, together with the extremely scarce presence of adjectives, is one of its most significant characteristics. It directly contributes to the stark, concentrated quality of Llull's prose; a quality which is enhanced by this author's partiality for 
indirect speech, of wich he is a master, as the succinct end of this episode will show:

Blanquerna aconselà lo pastor con degués consolar sa muller segons la manera que ell l'avia consolat; e dix al pastor que con diria a ssa mullar la mort de son fill, que li ensemps la mort de un frare de sa muller, lo qual sas muller molt amava, e que en aprés vengués son frare a consolar sa ssor, en la vida del qual hauria en axí consolació, con ell hac con entès que 1 lop no era sa muller. ${ }^{17}$

The prevalence of verbal forms accounts for the dynamic, swift pace of Llull's writing, while the nominal forms are reserved for the "special effects», as for instance in the first passage quoted above, where the tragic ruthlessness of the wolf's killing is made vividly concrete by the word corada; or in a later passage, when the shepherd, calmed down by Blanquerna, is now ready to receive his divine indoctrination:

Ab paciència, consolació, havent goig de tot ço que fa la justícia de Déu, e bavent alegrança en coracge, on sia fortitudo contra tristícia, e aver goig de aver prudència e utilitat, reebent dampnatge d'aquestes coses terrenals, és hom contra mort corporal e contra mort speritual; e concorda's hom ab vida celestial, qui per tots temps és perdurable. ${ }^{18}$

This excerpt also provides the reader with just about the complete range of Llull's adjetival uses, from which are missing the very important foyll, its counterpart savi and the ubiquitous bell.

A full-fledged planctus is incorporated into the episode of the pastor; its crits, plants and plors draw Blanquerna to the scene of the tragedy. Llull uses this lament indirectly to supply the reader with a few extra details of the incident, which add to its painful quality, details which are deeply moving to the reader and to Blanquerna himself:

17 Llull, Blanquerna, I, 253.

${ }^{18}$ Llull, Blanquerna, I, 25 I (emphasis added). 
A las, mesquí! Perdut has ço que méa amaves. Mort est ton fill; tu est occasió de sa mort, con, a força de sa mare, lo amenest en est boscacge. En tristícia e en dolor has mesa ta muller tots los jorns de sa vida... Devant ta muller estaràs vergonyós e colpable... Fill: ¿on és lo bell semblant que-m demostrava ton visacge? ${ }^{19}$

Here the imagination of the artist and the tender compassion of the man merge in depicting a moment of overwhelming emotion which realistically includes the shepherd's anticipation of his wife's grief and reproaches.

The questions that follow the first one above, although a convention common to the planctus genre, are far from being purely rhetorical in this instance: «¿Ni hon és anat lo gran plaer que'n avia mon coratge? Fill: la tua mort me fa desirar morir... d'aquí en avant, ¿qui serà en mon coracge?» They represent the natural expression of paternal despair at the loss of a cherished offspring, whose youth and vulnerability made him still an extension of the father's being. Rhetorical questions are often used by Llull in Blanquerna and usually follow the pattern established at the very beginning of the novel:

Los plors ni les devotes paraules qui foren entre els, ¿qui.ls vos puria recomptar? Ni les bones paraules que Blanquerna recomptà aquella nit de Déu e de sa glòria, qui u puria dir? Ni les benediccions que Evast e Aloma donaren a lur fill, qui les vos puria scriure? ¿Ni qui és qui-s pogués abstenir de plorar si ohís lurs paraules? ${ }^{20}$

Not so in the case of the shepherd's episode, where Llull the poet, with exquisite sensitivity, perceives the inappropriateness of any artificial devide to describe such profound human grief. By keeping his touch delicate, natural, and giving a succinct, factual account of the tragedy, he permits the pathos of the situation to mobilize the readers' emotional response rendering superfluous all formal rhetorical mediation.

19 Llull, Blanquerna, I 245-46.

${ }^{20}$ Llull, Blanquerna, I, 76-77. 
Blanquerna arrives on the scene drawn by the cries of the shepherd and by the "ladrament dels can qui-s combatien ab lo lop", another masterly descriptive touch. Eager to console the shepherd who "no fahia semblant quell veés ni que ohís ses paraules: tant era costret de la angoxa, dolor, que sostenia», Blanquerna decides to kill the wolf, and, seizing the shepherd's staff "vench vés lo lop abrivadament e com a home mugut a pietat per la mort del infant", Blanquerna's reaction, qualified by "abrivadament» and "mugut a pietat», reveals that he has been as deeply stirred as the reader by the shepherd's wailing, thus acquiring in this episode a measure of humanity that enriches his role as the exemplary saintly hero and that elicits in the reader a reaction of spontaneous empathy with him.

The killing of the wolf does not stir the shepherd who is, as the modern reader exposed to medical jargon easily recognizes, in a state of emotional shock. Ramon Llull describes this condition in a rigorously accurate manner:

Molt fo maravellat Blanquerna de la dolor quel pastor menava, e molt $n^{2}$ ach gran pietat, e penssà que per sobre gran ira e gran tristícia, avia lo pastor perduda sa memòria, e no havia de ell conexença ni de ses paraules... ${ }^{2 \mathrm{I}}$

The remedy he adopts for it, startling in its visionary eccentricity, proves to be a brillian example of his psychological acumen, and the most effective therapy:

Mort és ton fill; lo lop a morta ta muller e a morts tos cans - Lo pastor amava molt forment sa muller; e cuydà's que Blanquerna digués veritat... Vine'm, veuras ta muller, que 1 lop ha morta - . Lo pastor seguí Blanquerna tro al loch on era lo lop mort: - Aquesta és ta muller... Molt fo maravellat lo pastor de les paraules de Blanquerna, e pensà que ell agués perdut son seyn, o que lo lop fos sa muller. ${ }^{22}$

${ }^{21}$ Llull, Blanquerna, 1, 247.

${ }^{22}$ Llull, Blanquerna, $1,248$. 
Naturally, as Blanquerna had realistically anticipated, this second, contrived shock rouses the shepherd from his listlessness («Blanquerna viu que la memòria del pastor començava a revenir e a tornar en sa natura, e.l enteniment comencava a entendre») and makes him receptive to Blanquerna's ministrations of comfort.

The pace of narration in Blanquerna is generally very fast, collecting events and encounters in crowded succession. It becomes more and more urgent as Blanquerna's role reaches more elevated heights - Abbot, Bishop, finally Pope - and is rendered more complex by the manifold responsibilities traditionally inherent to these ecclesiastic ranks, and by the new duties Blanquerna himself devises to achieve the redemption of society. The whirlwind of reforms that sweeps in the path of Pope Blanquer$\mathrm{na}$ is vividly conveyed by the description of frenzied moments such as those to which this study referred earlier on. Their increased recurrence toward the end of the novel sets the stage for Blanquerna's decision to retire to contemplative life.

With the commencing of eremitic life Blanquerna the novel is virtually over. For Blanquerna the struggle between visionary hope and realistic cognizance is finally resolved, transcended into mystical contemplation. The modern reader, dazzled and intrigued by the tumultuous, swarning picture of mediaeval life through with Ramon Llull has guided him, and puzzled by the seemingly irreconcilable contradictions that have, unexpectedly, harmoniously contributed to the making of a great work of fiction, witnesses the transformation of Pope Blanquerna into the quaint anchorite of a stylized tableau:

En aquella abitació ach $\cdot \mathrm{I}^{\mathrm{a}}$ font molt bella e una capella ançiana, e hac una sel-la molt bella. Aprés, luny d'aquella capella un miller, hac una casa on stegués un home que servís Blanquerna e qui li aparellàs de menjar, e que Blanquerna pogués mills contemplar. Aquell home fo un diaque que Blanquerna molt ama- 
va, lo qual no-s volch partir de Blanquerna, en la companya del qual volch ésser Blanquerna per ço que li ajudàs tots jorns lo divinal ofici. ${ }^{23}$

Blanquerna's life story concludes here, at the end of chapter ninety-eight, with the depiction of the protagonist transformed into Blanquerna the Ascetic, his image recorded precisely and suggestively as he enters the frozen, conventional milieu which constitutes, in historical reality as well as in the book that has been discussed, the converse face of the mediaeval age. A face that is probably more familiar to the modern mind than the crowded, noisy scenes through which up to this point Blanquerna has wended his way, creating in his path the earliest novel to be written in Romance Europe.

There can be no doubt after reviewing some of the most characteristic narrative strategies of Llull in Blanquerna, that Llull's novelistic writing was as innovative as his approach to religious reform. Neither can there be any doubt that his artistry was self-consciously applied, in a fashion that anticipates narrative techniques of later centuries. This is most blatantly apparent in the manner in which Llull brings the book to an end. After the didactic and devotional interludes of the Libre d'Amich e Amat and Art de Contemplació, the narration returns for one brief concluding chapter to the fictional mode proper which Llull had adopted in the ninety-eight chapters devoted to Blanquerna's life. In Blanquerna's advice to the troubadour who had asked him for an appropriate penance to atone for the sins to which his art has exposed him and others, the reader witnesses the openended conclusion of the fictional parable:

On, per açò jo, bells amichs, vos dó penitència que vós anets per lo món cridant e cantant per uns huficis e per altres, dient la entenció per què fo juglaria ells altres uficis en lo començament; e portats aquest romanç de Evast e Blanquerna, en lo qual són significades les rahons per les quals foren atrobats los comença- 
ments demunt dits; e reptats e sobreprenets tots aquells qui husen mal de lurs uficis, segons vostre poder, en temps e loch e oportunitat, e no us temats blasme, treball, mort, per ço que a Déu siats agradable. ${ }^{24}$

By recommending that the troubadour make public the book of which he is the protagonist, Blanquerna anticipates a type of selfconscious posture such as Cervantes will employ in Don Quijote, the very posture which will lend to modern narrative one of its most distinctive characteristics. Blanquerna, a fictional creature summoned forth by Llull's imagination, effectively becomes the instigator of his own real literary legend:

Lo juglar pres penitència de Blanquerna, e reebia l'ufici que li hac donat, e anava per lo món recomtant per què era teologia, clerecia, religió, cavalleria, preladia, senyoria, merchaderia, metgia, dret, philosophia e les altres coses semblants a aquestes; e reprenia aquells qui no conservaven la final entenció per la qual eren atrobades les coses demunt dites, e ligia en les plaçes e en les corts e en los monestirs lo romanç de Evast e Blanquerna, per ço que muntiplicàs devoció e que ell n'agués major animositat, fortitudo, a complir sa penitència, que Blanquerna li havia donada. ${ }^{25}$

Conversely other characters, the Emperador, the Bisbe, the Juglar de Valor, step out of their timeless frame to perform the task of promoting and praising their author's timely, practical implementation of his missionary goals. Thus, the reader finds that the fictional Emperador urges the Bisbe to have the Juglar de Valor sing at the Papal court in Rome seven cobles in which real Lullian landmarks -Miramar, Mallorch - are mentioned, and the corruption of Church and State is attacked with a voice that is Llull's own:

[4]Remembrat han frares menors

lo Salvador, qui volch vestir

ab si lo sant religiós,

24 Llull, Blanquerna, 3, 180.

${ }^{25}$ Llull, Blanquerna, 3, 180-8I. 


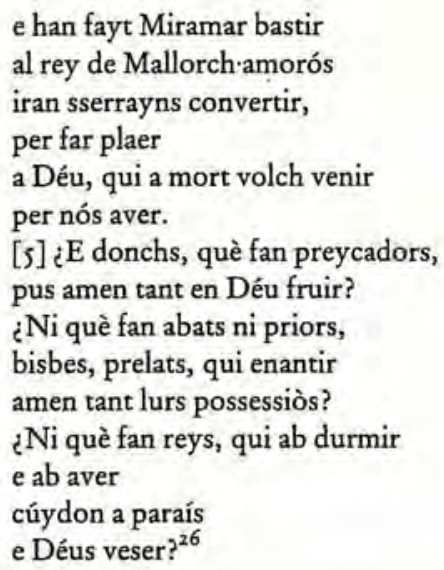

In a contradictory yet typical fashion however, the last verse ends with a reference not to the real Llull but to the fictional Blanquerna. And in the paragraph that follows - the last of the book - the reader receives definitive confirmation of the stylistic validity of the premeditated interplay of the visionary and the realistic:

Lo bisbe recomptà al emperador la santa vida de Blanquerna, e mostrà-li les encontrades en les quals puria trobar lo loch on vivia en vida ermitana. Molt plach al emperador ço quel bisbe li hac recomptat de Blanquerna ni com li hac mostrades les carreres per les quals lo puria atrobar. Lo bisbe pres les cobles e pres cumiat, molt agradablement, del emperador, e comanà'l a la benedicció de Déu. ${ }^{27}$

A mythicized Blanquerna lives on in an unspecified but accessible site to be visited and consulted by the Emperador, now also a would-be eremite. The Emperador, after the momentary transition into historical reality which Llull's verses represent, is reintegrated into a fictional realm on which Blanquerna will pre-

${ }^{26}$ Llull, Blanquerna, 3, 183 .

${ }^{27}$ Llull, Blanquerna, 3, $184-8 \mathrm{~s}$. 
side for ever. A realm which opens itself to an endless spectrum of future denouements (to be imagined by the reader) precisely because the boundaries between visionary and realistic representation are susceptible to transgression and have been so throughout the novel. In the multifaceted fecundity of this fundamental, and fundamentally novelistic, strategy ultimately lies the extraordinary power of Llull's writing in Blanquerna, and also its unique and largely unexamined contribution to the modern narrative genre.

ELENA ROSSI UNIVERSITY OF VICTORIA 